\title{
The Effect of Women's Decision Making Styles on Sustainable Consumption Behaviours
}

\author{
Burcu Savaş \\ Karabuk University, Faculty of Economics and Administrative Sciences \\ Department of Economics, Karabuk/Turkey \\ burcu_savas90@hotmail.com \\ Assoc.Prof. Gülay Günay \\ Karabuk University, Faculty of Economics and Administrative Sciences \\ Department of Economics, Karabuk/Turkey \\ ggunay@karabuk.edu.tr

\section{Assoc.Prof. Ayfer Aydiner Boylu} \\ Hacettepe University, Faculty of Economics and Administrative Sciences \\ Department of Family and Consumer Sciences, Ankara/Turkey \\ ayfer_boylu@hotmail.com
}

Doi:10.5901/ajis.2014.v3n3p288

\begin{abstract}
Economic activity is based on the continued availability of sufficient material and energy resources and on environment that is sufficiently clean and attractive. On the one hand fast increasing population and on the other hand a growing number of over consumption has caused environmental problems. All of these problems require new solutions for humanity. In this study we carried out to investigate women's decision- making styles effects on sustainable consumption behavior. Participants in the study consist of women who live in Safranbolu/Turkey. A total of 320 female (with an approximate \% 80 participation rate) are participated on a voluntary. Data were collected through a demographical information form, Consumer Style Inventory (CSI) and Sustainable Consumption Behaviors Scale (SCBS), to determine the factors affecting of women on sustainable consumption behaviors. The results demonstrated that female's age ranged from 19 to 83 in age ( $M=38.9, S D=9.8)$. The average income has been found 1.869,1 TL (=898,6 \$; 1 dollar is equivalent to about $2.08 \mathrm{TL}-$ May, 2014). The result of regression analysis revealed that demographic characteristic such as education, monthly family income and working status, decision-making style (factors Perfectionistic High-Quality Conscious, Habitual Brand-Loyal Consumer and Financial TimeEnergy Conserving) of women are important predictors of sustainable consumption behaviors ( $p<.001)$.
\end{abstract}

Keywords: women, sustainable consumption, decision making style, women consumption behaviors, consumer style inventory

\section{Introduction}

The economy and the natural environment interact. The condition of one is of importance to the other. On the one hand, economic activity is based on the continued availability of sufficient material and energy resources and an environment that is sufficiently clean and attractive. Insofar as the economy is based on renewable resources, the proper functioning of natural processes and systems may become an essential requirement for society's continuity (Opschoor and Reijnders, 1991). Current unsustainable patterns of consumption is imperative for the achievement of sustainable development in a world in which human population is projected to be 9,5 billion by 2050 , and in which about 1.2 billion people currently live in extreme poverty and deprivation (UN Population Division, 2013; World Bank, 2013). Changing consumption patterns is vital for poverty and hunger extermination, and also for protecting and managing the natural resource base and ecosystems, which underpin development. Unsustainable consumption patterns are increasing water and air pollution, land and forest poverty, waste generation and the use of harmful chemical substances. Current pressures on the planet's natural resources and life support systems will increase with population and economic growth unless consumption patterns become more efficient and less polluting (Millennium Ecosystem Assessment, 2005).

For many years, environmental policies were focused on the production side, mainly through pollution control and eco-efficiency. Household consumption patterns, and the drivers behind them, were poorly understood (OECD, 2002). Consumption levels and patterns of families are one of the primary drivers of sustainable consumption which defined as 
"the use of goods and services that respond to basic needs and bring a better quality of life, while minimizing the use of natural resources, toxic materials and emissions of waste and pollutants over the life cycle, so as not to jeopardize the needs of future generations" (Grover, Hemmati \& Flenley, 1999).

From a historical perspective, consumption has been associated with women (Cowan, 1987; Game \& Pringle, 1979). Indeed, women who are responsible for $80 \%$ of the consumption decision in households (Griffin, 2006; Kelan, 2008) and represent the largest group of consumers shopping for the daily needs of their families. Studies are also shows that in families, women are responsible for purchasing almost all household goods, while men make more consumption decisions with regard to automobiles and holidays (Heinzle and Känzig, 2010). So women's consumption decisions regarding food, clothes, medicines, household goods, education, etc. are keys in determining the sustainable consumption behaviors and better understanding of the consumption decision making style of women is needed.

A consumer decision-making style is defined as "a patterned, mental, cognitive orientation towards shopping and purchasing, which constantly dominates the consumer's choices (Sproles, 1985). Knowledge of consumer decisionmaking styles are clearly important because it is inseparable linked to purchase behavior and sustainable consumption.

Women have a greater tendency to make sustainable consumption choices, e.g. eating less meat, or a showing preference for organic food (Heinzle and Känzig, 2010). In empirical studies on environmental awareness and behavior in industrialized countries, clear gender differences have been detected repeatedly: women tend to have a higher level of environmental awareness than men, women show a higher engagement with environmental issues and a greater willingness to act to preserve the environment; women are more skeptical regarding new technologies and their potential impacts and risks; and women act in a more environmentally friendly manner, e.g. they buy more environmentally sound products; their mobility behavior is less environmentally harmful because they drive cars less often, walk more and use public transport more often than men (Gender CC, 2014). The research on gender and attitudes towards the environment does point in one direction: women show higher ecological awareness and also more environmentally sound behavior (Zelezny et al., 2000; OECD, 2008, Blocker \& Eckberg, 1989).

As surveys indicate, women in many cases pay more attention to environmental and ethical aspects of consumption; they are often key targets for sustainable consumption. However no attention has been paid to the question of how women's consumer decision making styles affect sustainable consumption behaviors. Therefore this study aims to increase understanding of the role of women in sustainable development.

\section{Method}

\subsection{Participation}

The sample group of this study consisted of women who have been dwelling in Safranbolu/Karabuk city, Turkey. Safranbolu is a town and district of Karabuk Province in the Black Sea region of Turkey. It is about 200 kilometers north of Ankara and about a $100 \mathrm{~km}$ south of the Black Sea coast. According to the 2013 census, the population of the locality is 55.170 , of which 31.697 live in the center of Safranbolu. Safranbolu is a town where receiving migration from outside, historical and touristic settlement. Due to the differences in socio-cultural and socio-economic structure this region are selected. The samples of the study consist of women who agreed to participate on a voluntary basis. In this context 400 women have interviewed in the study. Participants were contacted in person and surveys were given individually. Following the researcher's self-introduction, the purpose of the study was explained. After obtaining their consent, the survey packets, which subjects read and completed on their own, were distributed and then researchers collected all surveys once they were completed. Each participant was contacted individually and completed the questionnaire (27 women do not accepted the interview). Uncompleted and uncorrected questionnaire forms were not taken into consideration (53 questionnaire form was uncompleted or uncorrected). Finally, a total of 320 interviews were conducted with an approximate 80 percent participation rate. The data were collected between April 1-30 2012.

\subsection{Instruments and Data Collection}

In this study all variables analysis are self-reported measures.

Independent variables: Independent variables are age (age was coded the age in years at the time of the interview), marriage (1=single, 2=married), duration of marriage (duration of marriage was coded in years at the time of the interview), number of children, monthly family income (it was coded in years at the time of the interview), education level (1=Primary school, 2=High school, 3=Bachelor's and over), working status (1=worker, 2=non-worker) and family type (1=extended family, $2=$ =nuclear family). 
Sustainable Consumption Behavior Scale (SCBs): This scale developed by Kiracı and Karalar (2010). Sustainable consumption was measured using the Sustainable Consumption Behavior Scale (SCBs), which includes 36 items such as "I avoid products in aerosol containers." Responses were given on a 5-point Likert Scale, ranging from 1 ("never") to 5 ("every time"). 8, 13, 14, 15, 16 items was coded reverse. According to Kiracı and Karalar (2010) Cronbach's alpha coefficient was used to determine the internal consistency reliability of scale used. It was determined that alpha value for SCB scale was 0.63. SCB scales do not have high alpha values and so the scale could be improved in future research. But in this study Cronbach's Alpha coefficient was found .75.

Consumer Style Inventory (CSI): CSI was developed by Sproles and Kendall (1986) to determine understanding the consumer decision making styles. CSI scales include 40 items such as "Shopping is not a pleasant activity to me" and "The most advertised brands are usually good choices" Responses were given on a 5-point Likert Scale range from " $1=$ certainly disagree" to " $5=$ certainly agree". Original consumer decision making style inventory consist of eight factor structure named "1=Novelty, Brand Conscious Consumer, 2=Perfectionistic, High-Quality Conscious, 3=Confused by Overchoice Consumer, 4=Recreational, Hedonistic Conscious, 5=Impulsive, Careless Consumer, 6=Variety-Seeking Consumer, 7=Habitual, Brand-Loyal Consumer, 8=Financial, Time-Energy Conserving". Internal consistency of the inventory was measured with Cronbach Alpha. The scale was adapted to the Turkish culture by Dursun et al. (2013). According the results of Dursun et al. (2013) a suitable model of CSI for Turkish consumer consists of nine factor structures. However in this study factor analysis results showed that factor structure has coincide with original CSI.

Questionnaires are arranged in accordance with the aim of the research. The questionnaire was pretested by applying to 15 women in order to evaluate the conformity of the questionnaire. The form was rearranged through the suggestions came from this pretest group and the required corrections were made.

\subsection{Data Analysis}

The analysis of the data was conducted using the "SPSS for Windows 15.0" program. Data analysis began with calculating frequencies of the sample on all variables and the graphs for these distributions were obtained. Mean and standard deviation for the scales used in the study were calculated.

Correlation analysis was performed to determine the level and direction of the relationship between the dependent and independent variables, and regression analysis was used to determine the sequence of contribution for the variables (Büyüköztürk, 2007:91). In this study, regression analysis were performed to find out whether some variables related to demographic variables (age, education level, monthly family income, working statutes), factors of CSI (Variety-Seeking Consumer, Novelty, Brand Conscious Consumer, Perfectionistic, High-Quality Conscious, Confused by Overchoice Consumer, Impulsive, Careless Consumer, Habitual, Brand-Loyal Consumer, Recreational, Hedonistic Conscious and Financial, Time-Energy Conserving) have any effect on the sustainable consumption behaviors. Also independent sampling t-test and ANOVA have performed to identify if there is a meaningful difference between demographic variables (age, education level, monthly family income, working statutes) and sustainable consumption behavior (Büyüköztürk, 2007:30)

\section{Results}

\subsection{Participants}

The participants were 320 female who have dwelling in Safranbolu/TURKEY. The aged of the interviewers ranged from 19 - 83 years $(M=38.2, S D=10.0)$ and the present of $33.1 \%$ participants was " $35-44$ years old" age group. The waste majority of the participants are married (95.6\%). The average length of marriage is sixteen $(M=16.1 ; S=11.0)$ years, with a range from one to fifty-seven years. The income of the females ranged from 100,00 TL to 15.000,00 TL, and the average income is $1.869,1 \mathrm{TL}(=898,6 \$-1$ dollar is equivalent to about 2,08 TL - June,2014). According to a study by the TÜRK-IŞ (Confederation of Trade Unions of Turkey) Research and Development Center in July 2013, the starvation line is approximately 1.011,84 TL (about 500 \$) (TÜRK-ISS, 2014). Thus, the sample group consisted of middle socioeconomic level families. The findings shows that 50.6 percentage of the female have primary school (8 years) education degree, 25.6 percentage have high school (11 years) education degree, 23.8 percentage have Bachelor's and over (15 and over years) education degree. The rates of non-worker females (65.6\%) are higher than the rate of worker females (34.4\%). It is determined that $60.0 \%$ of the females who are non-worker, are housewife and out of the total worker females ( $n=110)$, $17.5 \%$ are servant and $10.9 \%$ of them are employee. About $36.9 \%$ of the participants had 2 children, $27.5 \%$ had $1,15.3$ $\%$ had $3,10.6 \% 4$ or more and 9.7 percent had no children. In addition, the majority of the individuals lived in a nuclear 
family.

Table 1. Demographic Characteristics of the Sample

\begin{tabular}{|c|c|c|c|c|c|}
\hline Marriage & $\mathbf{F}$ & $\%$ & Age & $\mathrm{F}$ & $\%$ \\
\hline Single & 14 & 4.4 & $\leq 24$ & 20 & 6.3 \\
\hline Married & 306 & 95.6 & $25-34$ & 104 & 32.5 \\
\hline Duration of marriage & $F$ & $\%$ & $35-44$ & 106 & 33.1 \\
\hline$<5$ & 68 & 21.3 & $45-54$ & 68 & 21.3 \\
\hline $6-15$ & 98 & 30.6 & $\geq 55$ & 22 & 6.9 \\
\hline $16-25$ & 88 & 27.5 & Number of children & $\mathrm{F}$ & $\%$ \\
\hline$>26$ & 66 & 20.6 & 0 & 31 & 9.7 \\
\hline Education & $\mathbf{F}$ & $\%$ & 1 & 88 & 27.5 \\
\hline Primary school (8 years) & 162 & 50.6 & 2 & 118 & 36.9 \\
\hline High school (11 years) & 82 & 25.6 & 3 & 49 & 15.3 \\
\hline Bachelor's and over (15 + years) & 76 & 23.8 & 4 or more & 28 & 10.6 \\
\hline Working status & $\mathbf{F}$ & $\%$ & Family type & $\mathbf{F}$ & $\%$ \\
\hline Worker & 210 & 65.6 & Extended family & 47 & 14.7 \\
\hline Non-worker & 110 & 34.4 & Nuclear family & 273 & 85.3 \\
\hline Monthly family income & $\mathbf{F}$ & $\%$ & & & \\
\hline Low & 177 & 55.3 & & & \\
\hline Middle & 111 & 34.7 & & & \\
\hline High & 32 & 10.0 & & & \\
\hline
\end{tabular}

The statistical analysis results of t-test showed that working status of females significantly affected scores on the SCB scale. It can be said that non-worker females sustainable consumption behavior scores ( $M=118.0, S D=11.5)$ are a bit higher than that of worker females $(M=109.2, S D=11.7)(t=2.794, d f=318, p>05)$. However there was no significantly relationship between participants' scores on the SCB scale and females age ( $F=0.660 ; d f=4-315 ; p<.05)$, education $(F=1.056 ; d f=2-317 ; p<.05)$ and monthly family income ( $F=0.476 ; d f=4-315 ; p<.05)$.

Table 2. ANOVA and T-Test analysis between independent variables and sustainable consumption behavior

\begin{tabular}{|c|c|c|c|c|}
\hline Age & $\mathbf{N}$ & Mean & $\mathbf{S}$ & significant \\
\hline$\leq 24$ & 20 & 110.3 & 14.2 & \multirow{5}{*}{$F=0.660 ; d f=4-315 ; .620$} \\
\hline $25-34$ & 104 & 111.6 & 10.5 & \\
\hline $35-44$ & 106 & 109.1 & 12.6 & \\
\hline $45-54$ & 68 & 110.9 & 12.2 & \\
\hline$\geq 55$ & 22 & 111.2 & 9.4 & \\
\hline \multicolumn{5}{|l|}{ Education } \\
\hline Primary school (8 years) & 162 & 109.8 & 12.8 & \multirow{3}{*}{$F=1.056 ; d f=2-317 ; .349$} \\
\hline High school (11 years) & 82 & 110.4 & 11.8 & \\
\hline Bachelor's and over ( $15+$ years $)$ & 76 & 112.2 & 9.1 & \\
\hline \multicolumn{5}{|l|}{ Monthly family income } \\
\hline Low & 177 & 110.9 & 11.8 & \multirow{3}{*}{$F=0.476 ; d f=4-315 ; .622$} \\
\hline Middle & 111 & 109.7 & 12.4 & \\
\hline High & 32 & 111.4 & 9.6 & \\
\hline \multicolumn{5}{|l|}{ Working status } \\
\hline Worker & 210 & 109.2 & 11.7 & \multirow{2}{*}{$\mathrm{t}=-2.794 ; \mathrm{df}=318 ; .006^{* *}$} \\
\hline Non-worker & 110 & 113.0 & 11.5 & \\
\hline
\end{tabular}

Pearson Product Moment correlations were used to establish the relationship between the independent and dependent variables. Results presented in Table 3 show that there was significant positive relationships between females sustainable consumption behaviors and monthly family income (.125, $p<.05)$, working status (.155, $p<.01)$, Perfectionistic, High-Quality Conscious (.176, $p<.01)$, Habitual, Brand-Loyal Consumer (.117, $p<.01)$, Financial, Time-Energy Conserving $(.135, p<.01)$. 
Table 3. Pearson Correlations between Sustainable Consumption Behavior and Independent Variables

\begin{tabular}{|c|c|}
\hline Independent Variables & SCB \\
\hline Age & .023 \\
\hline Education & .001 \\
\hline Monthly family income & $.125^{*}$ \\
\hline Working status & $.155^{\star \star}$ \\
\hline Variety-Seeking Consumer & -.004 \\
\hline Novelty, Brand Conscious Consumer & .081 \\
\hline Perfectionistic, High-Quality Conscious & $.176^{* \star}$ \\
\hline Confused by Overchoice Consumer & .056 \\
\hline Impulsive, Careless Consumer & -.016 \\
\hline Habitual, Brand-Loyal Consumer & $.117^{*}$ \\
\hline Recreational, Hedonistic Conscious & .108 \\
\hline Financial, Time-Energy Conserving & $.135^{*}$ \\
\hline
\end{tabular}

Multiple regression analyses were used to ascertain factors that are significant in predicting females' sustainable consumption behavior. Table 4 shows the results of multiple regression analyses for the sustainable consumption behaviors. For the first stage of the multiple regression analyses only the demographic factors, such as age, education, monthly family income and working status included to the analysis. In the second stage, eight factors of consumer decision-making style inventory are added to the regression along with the demographic factors. The determination coefficients $\left(R^{2}\right)$ obtained at the end of two stages were compared and the variables are evaluated for participants.

Demographic variables explain $5 \%$ of the total variance on the SCBs for the females participants $(R=0.227$, $\left.R^{2}=0.051, F=4.274, p<.01\right)$. Table 4 gives the t-test results related to significance and the regression coefficient $(\beta)$ standardized to test the effect of the independent variables, in the first stage of the analysis, on females sustainable consumption behavior. Education $(\beta=.18, p<.01)$, monthly family income $(\beta=-.16, p<.01)$, and working status $(\beta=.17$, $p<.01)$ have significant effect on females sustainable consumption behavior.

The second stage was run by including factors of consumer decision-making style factors (CSI) (variety-seeking consumer, novelty, brand conscious consumer, perfectionistic, high-quality conscious, confused by overchoice consumer, impulsive, careless consumer, habitual, brand-loyal consumer, recreational, hedonistic consumer and financial, timeenergy conserving) to regression equations. The results illustrated that the stage was significant of females participation and explained $13 \%$ of total variance $\left(R=0.360, R^{2}=0.130, F=3.503, p<.001\right)$. Additionally finding indicated that among females participants the relationships between Sustainable Consumption Behavior and Perfectionistic, High-Quality Conscious ( $\beta=.17, p>.05)$, Habitual, Brand-Loyal Consumer $(\beta=.12, p>.05)$ and Financial, Time-Energy Conserving $(\beta=.12, p>05)$ were statistically significant (Table 4).

Table 4. Multiple Regression Analysis

\begin{tabular}{|c|c|c|c|c|c|c|c|}
\hline Independent Variables & $\bar{B}$ & SH & $\bar{\beta}$ & $\bar{F}$ & $\bar{p}$ & $\mathbf{R}$ & $R^{2}$ \\
\hline Step 1 & 97.126 & 4.293 & & 4.274 & .002 & .227 & .051 \\
\hline Age & 137 & .072 & .116 & & & & \\
\hline Education & 1.338 & .554 & $.181^{*}$ & & & & \\
\hline Monthly family income & -.002 & .001 & $-.161^{\star}$ & & & & \\
\hline Working status & 4.215 & 1.628 & $.170^{*}$ & & & & \\
\hline Step 2 & 99.510 & 4.267 & & 3.503 & .000 & .360 & .130 \\
\hline Age & 109 & .075 & .093 & & & & \\
\hline Education & .836 & .562 & .113 & & & & \\
\hline Monthly family income & -.002 & .001 & -.154 & & & & \\
\hline Working status & 4.776 & 1.594 & .193 & & & & \\
\hline Variety-Seeking Consumer & .106 & .656 & .009 & & & & \\
\hline Novelty, Brand Conscious Consumer & .935 & .675 & .079 & & & & \\
\hline Perfectionistic, High-Quality Conscious & 2.029 & .638 & $.172^{\star}$ & & & & \\
\hline Confused by Overchoice Consumer & .671 & .631 & .057 & & & & \\
\hline Impulsive, Careless Consumer & -.145 & .633 & -.012 & & & & \\
\hline Habitual, Brand-Loyal Consumer & 1.391 & .633 & $.118^{*}$ & & & & \\
\hline Recreational, Hedonistic Conscious & 1.159 & .633 & .098 & & & & \\
\hline Financial, Time-Energy Conserving & 1.461 & .653 & $.124^{*}$ & & & & \\
\hline
\end{tabular}




\section{Discussion and Conclusion}

This paper gives place to various definitions about factors that affect sustainable consumption behavior and then presented the findings of a research. The objective of this research was to investigate effects of women's decision making styles on sustainable consumption behaviors previously studied in the developed countries. Prior studies have reported that women are more concerned than men about social issues (Eagly et al. 2004) and are also more concerned about the environment (Koos 2011; Zelezny et al. 2000). Roberts (1996) reported that women are more likely than men to be socially responsible in their consumption behaviors.

Analyses of the data from 320 women of diverse age, educational levels, monthly family income and working status showed difference significant effect on sustainable consumption behavior. Following the examination of demographic variables and SCBs, ANOVA and $t$ - test is carried out for the remaining variables. The t-test result is showed significant $(p<.05)$ differences between working status and SCBs. Based on the results of this study, it can be concluded that two groups of respondent (workers and non-workers) differed in some of their sustainable consumption behavior. The status of women is one factor that has effects on sustainable development (Ukpore, 2009). For example Heinzle and Känzig (2010) have found that women without employment are more cost sensitive than women with paid employment due to tighter budget constraints. However the results of ANOVA have no significant relationship between SCBs and educational levels, monthly family income and age group. These results may be consisting of due to the small size of sample. In contrast to this finding literature have supported educated people who have higher income tend to more sustain in their behaviors (Cortese, 2003; Haron et al., 2005; UNESCO, 2006)

In addition, regression analysis showed that demographic variables significantly predicted sustainable consumption behavior of women's. Although two different regression models were significant, the multi regression analysis indicated that only educational levels, monthly family income and working statutes have independent impacts on sustainable consumption behavior. In the second stage of the regression model factors of consumer decision making style as; Perfectionistic, High-Quality Conscious, Habitual, Brand-Loyal Consumer, Financial, Time-Energy Conserving have independent impacts on sustainable consumption behavior. Thus, considering the socioeconomic circumstances of Turkey, it seems likely that people which have higher education, higher earnings and having a high quality of life tend to be more sustainable (Gatersleben, Steg \& Vlek, 2002; Haron, Paim \& Yahaya, 2005).

Finally it seems that women make more ethical consumer choices, paying closer attention to issues including child labor and sustainable livelihoods and are more apt to buy socially labeled goods such as Fair-trade. Sustainable consumer behaviors (SCB) and the underlying mechanisms via which consumers make or fail to make socially and environmentally responsible choices are increasingly important topics for policy makers and for marketing practitioners and accordingly have been the object of increasing research attention and theory development in consumer research. The results of this research have significant implications for policymakers and educators in their search of strategies for improving the roles of women's' to sustainable development. The ability to act as a responsible and democratic citizen is a prerequisite for a sustainable development. This skill can be improved by reaching the recent knowledge and lifelong learning.

The present research has the characteristics of a pilot study conducted on the women decision making styles on sustainable consumption behaviors. Similar research recently conducted in Turkey and in other countries should be investigated from different perspectives in order to make a satisfactory comparison. To this end, the conducting of similar research, with sample groups with different features, different demographics, and socio-economic and socio-cultural features in different regions. New research on this issue would not only ensure comparisons being made between different variables and groups, but it would also provide a data set that could reveal factors affecting the changes, by the repeating of such research over a certain period of time.

\section{References}

Barletta, M. (2003). Marketing to Women. How to Understand, Reach, and Increase your Share of the World's Largest Market Segment. Chicago: Dearborn Trade Publishing.

Blocker, T. J. \& Eckberg, D. L. (1989). Environmental Issues as Women's Issues: General Concerns and Local Hazards, Social Science Quarterly, 70(3), 586-593.

Büyüköztürk, Ş. 2007, Sosyal Bilimler için Veri Analizi El Kitabı (Handbook of Data Analysis for the Social Sciences), 7.Baskı, Ankara: Pegem A Yayıncılık.

Cortese, A. (2003). The Critical Role of Higher Education in Creating a Sustainable Future. Planning for Higher Education 31;3:15-22.

Cowan, R.S. (1987). The Consumption Junction: A Proposal for Research Strategies in the Sociology of Technology. In W. E. Bijker, T. P. Hughes \& T. J. Pinch (Eds.), The Social Construction of Technological Systems. New Directions in the Sociology and History 
of Technology (261-280), London.

Dursun, İ. Alnıaçık, Ü. and Tümer Kabadayı, E. (2013). Tüketici Karar Verme Tarzları Ölçeği: Yapısı ve Boyutları (The Scale of Consumer Styles Inventory: Structure and Dimensions) Int. Journal of Management Economics and Business, 9, 19, 293 - 304.

Eagly, A.H., Diekman, A. B., Johannesen-Schmidt, M. C., \& Koenig, A. M. (2004). Gender gaps in sociopolitical attitudes: A social psychological analysis. Journal of Personality and Social Psychology, 87, 796-816.

Game, A. \& Pringle, R. (1979). Sexuality and the Suburban Dream, Journal of Sociology, 15(2), 4-15.

Gatersleben, B., Steg, L. \& Vlek, C. (2002). Measurement and Determinants of Environmentally Significant Consumer Behavior, Environment and Behavior, 34(3), 335-362.

Gender CC (2014). Gender, Climate Change and Consumption. Retrieved May 02, 2014 from: http://www.gendercc.net/fields /consumption.html

Grazia, V.D. \& Furlough, E. (1996). The Sex of Things. California: University of California Press.

Griffin, C. (2006). Feminine Mystique, SGB, 39(3), 18-19.

Grover, S., Hemmati, M., \& Flenley, C. (1999). Gender and Sustainable Consumption. Bringing Policy Gaps in the Context of Chapter 4, Agenda 21 Changing Consumption and Production Patters. Report submitted to CSD-7.

Haron, S., Paim, L. and Yahaya, N. (2005). Towards sustainable consumption: an examination of environmental knowledge among Malaysians. International Journal of Consumer Studies, 29; 5: 426 - 436.

Heinzle, S., Kanzig, J., Nentwich, J., \& Offenberger, U. (2010). Moving beyond gender differences in research on sustainable consumption: Evidence from a discrete choice experiment. Working paper No. 6 within the project Soziale, ökologische und ökonomische Dimensionen eines nachhaltigen Energiekonsums in Wohngebäuden. Retrieved May 5, 2014 from: http://kooperationen.zew.de/fileadmin/user_upload/Redaktion/Seco@home/nachhaltiger_Energiekonsum/Werkstattberichte/Gend er Werkstattbericht6.pdf

Kelan, E. (2008). Bound by Stereotypes? Business Strategy Review, 19(1), 4-7.

Kiracı, H. and Karalar, R. (2010). Bireysel Değerlerin Sürdürülebilir Tüketim Davranışı Üzerindeki Etkisini Belirlemeye Yönelik Öğretmenler Üzerinde Bir Araştırma (A Research on Class Teachers Related to Determining the Effects of Consumers' Personal Values on Sustainable Consumption Behavior). İşletme Araştırmaları Dergisi 2;2:79-106

Koos, S. (2011). Varieties of environmental labeling, market structures, and sustainable consumption across Europe: A comparative analysis of organizational and market supply determinants of environmental labeled goods. Journal of Consumer Policy, 34, 127151.

Millennium Ecosystem Assessment (2005). Ecosystems and Human Well-Being: Synthesis. Washington DC: Island Press.

OECD (2002). Towards Sustainable Household Consumption? Trends and Policies in OECD Countries. Retrieved April 16, 2014, from: http://www.oecd.org/dataoecd/28/49/1938984.pdf

OECD (2008). Gender and Sustainable Development. Maximizing the Economic, Social and Environmental Role of Women. Retrieved 14 May, 2014, from: www.oecd.org/dataoecd/58/1/40881538.pdf

Opschoor H. and Reijnders L. (1991). Towards Sustainable Development Indicators. In Search of Indicators of Sustainable Development. Environment \& Management. 1;7-27

Pettigrew, J.H. (2000). Women Mean Business. The Secret of Selling to Women. New York: Creative Consortium Books.

Roberts, J. A. (1996). Will the real socially responsible consumer please step forward? Business Horizons, 39, 79-83.

Sproles, G.B. (1985). From Perfectionism to Fadism: Measuring Consumers' Decision-Making Styles, Proceedings, American Council on Consumer Interests, 79-85.

TÜRK-IŞ (2014). Açlık ve Yoksulluk Sınırı (Starvation and Poverty Boundary) Retrieved: May 5 2014 from: http://www.turkis.org.tr/source.cms.docs/turkis.org.tr.ce/docs/file/aclikocak14.pdf

Ukpore, (2009). Sustainable Development in Nigeria: Roles of Women and Strategies for Their Improvement. Journal of Sustainable Development in Africa. 10;4:268-283.

UN Population Division (2013). World Population Prospects 2012 revision. Retrieved April 12,2014,from http://esa.un.org/wpp/ Documentation/pdf/WPP2012_\%20KEY\%20FINDINGS.pdf

UNESCO (2006). Education for Sustainable Development Action. Learning Training Tools. Retriewed: 03, 08, 2012. from: http://unesdoc.unesco.org/images/0015/001524/152453eo.pdf

World Bank (2013). Global Monitoring Report 2013: Rural-Urban Dynamics and the Millennium Development Goals. Washington DC, World Bank.

Zelezny, L. C., Chua, P.-P., \& Aldrich, C. (2000). Elaborating on gender differences in environmentalism. Journal of Social Issues, 56, 443-457. 